\title{
Factors associated with body image dissatisfaction in Portuguese adolescents: obesity, sports activity and TV watching
}

\author{
Eduarda Maria Coelho ${ }^{1,2^{*}}$, Sandra Celina Fonseca ${ }^{1}$, Graça Sofia Pinto1, Maria Isabel Mourão- \\ Carvalhal $^{2}$
}

This cross-sectional study intended to determine the prevalence of body image dissatisfaction and associated factors in Portuguese adolescents $(\mathrm{N}=529,10-18$ years, $53.7 \%$ male and $46.3 \%$ female). The prevalence of body dissatisfaction (estimated through Collins's silhouettes) was $58 \%$. Multivariate logistic regression analyses showed that the variables associated were: obesity, watch TV over 2 hours/day and practice sport activities 4 or more days/week. In male, obesity and watch TV over 2 hours/day were related to body dissatisfaction and among female only obesity had statistical significance. It is necessary to considered different public health interventions for men and women in order to reduce this high body image dissatisfaction.

Keywords: Body image, adolescence, gender, obesity, sports activity

\section{INTRODUCTION}

Body image was defined as "the picture we have in our minds of the size, shape and form of our bodies; and our feelings concerning these characteristics and our constituent body parts" (Slade, 1994). Young people show great concern with body image from an early age. Dohnt and Tiggemann (2006) found that body image concerns are relevant and present in young girls from 5 to 8 years of age. Body image dissatisfaction seems to increase with age, peaking during early adolescence, particularly among females (Littleton \& Ollendick, 2003). Recent investigations have shown that dissatisfaction with body size is a common concern among both female and male adolescents. A transcultural study conducted by Al Sabbah et al. (2009) among schoolchildren (11-15 years old) in 24 countries showed an increased body weight dissatisfaction with age, and a higher prevalence in girls and obese adolescents. The higher values of body weight dissatisfaction for girls were in the Czech
Republic (61.8\%) and for boys in Italy (39.9\%). In Portugal, this prevalence was $23.9 \%$ for boys and $44.0 \%$ for girls. Recent studies also confirm that girls show a more negative body image comparing with boys (Kantanista, Osiński, Borowiec, Tomczak, \& Król-Zielińska, 2015; Santana et al., 2013).

Body dissatisfaction is the attitudinal component of body image (the other is the perceptual component), involving the person's negative thoughts and feelings about his or her own body and associated with low self-esteem, eating disorders, depression and suicide attempt (Kim \& Kim, 2009; Shin \& Shin, 2008; Stice \& Bearman, 2001; Stice, Hayward, Cameron, Killen, \& Taylor, 2000; van den Berg, Mond, Eisenberg, Ackard, \& Neumark-Sztainer, 2010). Such conditions affect adolescents' health and quality of life. Despite this evidence, few studies have analyzed the risk factors that can predict body dissatisfaction, especially in Portugal.

Several sociocultural, biologic, and interpersonal factors that may promote body

\footnotetext{
Manuscript received at December $4^{\text {th }} 2014 ;$ Accepted February $16^{\text {th }} 2016$

1 Sports Science, Exercise \& Health Department of University of Trás-os-Montes and Alto Douro, Vila Real, Portugal

${ }^{2}$ Research Center in Sports Sciences, Health and Human Development (CIDESD)

* Corresponding author. Universidade de Trás-os-Montes e Alto Douro, Complexo Desportivo da UTAD, DCDESECVA, Quinta de Prados, 5000-801 Vila Real, Portugal E-mail: ecoelho@utad.pt
} 
dissatisfaction have been identified: gender (Alikasifoglu, Ercan, Erginoz, AlbayearakKaymak, \& Uysal, 2011; Almeida, 2004; Duca et al., 2010; Fidelix, Silva, Pelegrini, Silva, \& Petroski, 2011) age (Almeida, 2004; Duca et al., 2010; Silva, Nahas, de Sousa, Del Duca, \& Peres, 2011), obesity (Alikasifoglu et al., 2011; Almeida, 2004; Costa \& Vasconcelos, 2010; Duca et al., 2010; Gilbert-Diamond, Baylin, MoraPlazas, \& Villamor, 2009; Martins, Pelegrini, Matheus, \& Petroski, 2010; Petroski, Pelegrini, \& Glaner, 2009; Santana et al., 2013; Silva et al., 2011; Triches \& Giugliani, 2007), socioeconomic status (Almeida, 2004; Silva et al., 2011; Triches \& Giugliani, 2007), physical activity (Burgess, Grogan, \& Burwitz, 2006; Gaspar, Amaral, Oliveira, \& Borges, 2011; Kirkcaldy, Shephard, \& Siefen, 2002; Kruger, Lee, Ainsworth, \& Macera, 2008; Silva et al., 2011), hours watching TV (Alikasifoglu et al., 2011), unhealthy food patterns (Alikasifoglu et al., 2011), skipping meals (Duca et al., 2010) and alcohol habits (Silva et al., 2011).

Today a sedentary lifestyle and hyper-caloric food pattern are the leading causes of weight gain and obesity, and in Western societies, the adoption of thinner body models has led to higher body image dissatisfaction. To provide effective intervention, it is important to know the risk factors to identify the etiology of body dissatisfaction in Portuguese adolescents. In this context, we aimed to determine the prevalence of body image dissatisfaction and associated factors in Portuguese adolescents, stratified by gender.

\section{METHOD}

This study was approved by the Ethics Committee of Research Center in Sports, Health Sciences and Human Development and followed all ethical aspects in the Declaration of Helsinki, which was recently published by Harriss and Atkinson (2009).

\section{Sample}

A cross-sectional study was conducted in 2013, to assess body image dissatisfaction among adolescents in a North Portugal public school. The convenience sample was composed of 529 adolescents aged 10-18 (13.32 \pm 1.59 years), of both genders ( $53.7 \%$ male and $46.3 \%$ female).

\section{Instruments and Procedures}

Body Image Measure

Body shape perception was measured using a modified Stunkard Body Rate Scale developed by Collins (1991). The pictorial scale consisted of seven images of boys and girls, each image corresponding to an increase in shape, from very thin (silhouette 1) to obese (silhouette 7). Each subject identified the figure that best represented his/her body shape (representing current body) and the figure that they would like to have (desired and ideal body). Body dissatisfaction was estimated by the current minus the ideal body, with values ranging from -8 to 8 . Positive scores indicate that the subject is dissatisfied by being heavier than ideal; negative that the subject is dissatisfied by being lighter than ideal and a score of zero indicates satisfaction with body shape. Adolescents were tested individually in a private space at school. Psychometric research on this scale indicates a good concurrent validity in Portuguese children (Coelho, Padez, Moreira, Rosado, \& Mourão-Carvalhal, 2013). In this study, the Spearman correlation coefficient between body image and Body Mass Index (BMI) of .60 also indicates a good concurrent validity.

\section{Anthropometric Measures}

Standard procedures for anthropometric measurements (height and weight) were performed by two trained technicians on lightly dressed and barefoot adolescents. Height and weight were measured using a stadiometer, with the head positioned according to the Frankfort plane, and an electronic scale with a precision of 100 g. BMI was calculated (weight/height ${ }^{2}$, $\mathrm{Kg} / \mathrm{m}^{2}$ ) and the sample was classified as normal weight, overweight and obese based on average centiles (Cole, Bellizzi, Flegal, \& Dietz, 2000). Later in this study, the "obese" group includes overweight and obese adolescents.

\section{Lifestyle and Socioeconomic Status}

Lifestyle, socioeconomic status (SES) and demographic characteristics were obtained by questionnaire. This questionnaire was designed 
to collect information about factors that may be associated with body dissatisfaction. Gender, age (categorized in $\leq 13.5$ and $>13.5$ years old), parents' level of education ( $\leq 4$ years, 5-6 years, $\geq 7$ years), time spent watching TV ( $1 \mathrm{hr} /$ day, 2 hrs/day, $\geq 3 \mathrm{hrs} /$ day), frequency of sports activities (0-1 day/week, 2-3 days/week, $\geq 4$ days/week), alcohol and tobacco consumption (yes, no), three meals daily (yes, no), frequency of soft drink consumption (never, weekly, daily) and fruit consumption (never, weekly, daily) were the variables chosen to include in regression models.

\section{Statistical analysis}

Prevalence of body dissatisfaction was calculated in percentage and qui-squared tests in order to analyze the association with gender and obesity.

Logistic regression analyses (univariate and multivariate expressed by odds ratios in $95 \%$ confidence intervals) based on the maximum likelihood method were used to investigate the association of lifestyle and SES factors with the prevalence of body image dissatisfaction. After identifying the variables associated with body dissatisfaction separately, only were include in multivariate logistic regression, those that were significant $(\mathrm{p} \leq .20)$. The multivariate model analyzed all the variables together, adjusted for the remaining independent variables (obesity, father education level, sports activity, TV weekday and fruit).

\section{RESULTS}

The general characteristics of the sample are presented in Table 1.

Of the total sample $22.9 \%$ were overweight and obese. During free-time activities $51.8 \%$ spent 0-1 days/week in sports activities and $51.8 \%$ watched TV more than three hours per day. Alcohol consumption and smoking percentages were $5.1 \%$ and $16.1 \%$, respectively. Regarding daily eating behavior, $24.6 \%$ of adolescents had fewer than three meals per day, $38 \%$ consumed soft drinks and $56.5 \%$ ate fruit.

The prevalence of body dissatisfaction was $58 \%$ (see Table 2), with a higher percentage of those who wanted to be thinner (44.6\%). Gender was not significantly associated with body dissatisfaction $\left(\chi^{2}(1)=1.45, \mathrm{p}=.251\right)$. However, this association becomes significant when we analyze whether adolescents wish to have thinner or larger bodies $\left(\chi^{2}(2)=6.72, \mathrm{p}=.035\right)$. More girls (50.2\%) than boys (39.8\%) wished to have a thinner body, while more boys wanted to be larger ( $15.8 \%$ vs. $10.6 \%)$.

Table 1

\begin{tabular}{|c|c|c|c|}
\hline Variables & Levels & $\mathrm{N}$ & $\%$ \\
\hline \multirow{2}{*}{ Gender } & Male & 284 & 53.7 \\
\hline & Female & 245 & 46.3 \\
\hline \multirow{2}{*}{ Age } & $\leq 13.5$ years & 282 & 53.3 \\
\hline & $>13.5$ years & 247 & 46.7 \\
\hline \multirow{2}{*}{ Obesity } & Normal Weight & 408 & 77.1 \\
\hline & Obese & 121 & 22.9 \\
\hline \multirow{3}{*}{ Mother Educational Level } & $\leq 4$ years & 176 & 33.7 \\
\hline & $5-6$ years & 189 & 36.2 \\
\hline & $\geq 7$ years & 157 & 30.1 \\
\hline \multirow{3}{*}{ Father Educational Level } & $\leq 4$ years & 192 & 37.6 \\
\hline & $5-6$ years & 186 & 36.4 \\
\hline & $\geq 7$ years & 133 & 26.0 \\
\hline \multirow{3}{*}{ Sports Activity } & 0-1 day/week & 274 & 51.8 \\
\hline & 2-3 days/week & 127 & 24.0 \\
\hline & $\geq 4$ days/week & 128 & 24.2 \\
\hline \multirow{3}{*}{ TV(weekday) } & 1 hour/day & 99 & 18.7 \\
\hline & 2 hours/day & 156 & 29.5 \\
\hline & $\geq 3$ hours/day & 274 & 51.8 \\
\hline \multirow{2}{*}{ Smoking } & No & 502 & 94.9 \\
\hline & Yes & 27 & 5.1 \\
\hline \multirow{2}{*}{ Alcohol } & No & 444 & 83.9 \\
\hline & Yes & 85 & 16.1 \\
\hline \multirow{2}{*}{3 meals } & No & 130 & 24.6 \\
\hline & Yes & 399 & 75.4 \\
\hline \multirow{3}{*}{ Soft Drinks } & Never & 14 & 2.6 \\
\hline & Weekly & 314 & 59.4 \\
\hline & Daily & 201 & 38.0 \\
\hline \multirow{3}{*}{ Fruit } & Never & 6 & 1.1 \\
\hline & Weekly & 224 & 42.3 \\
\hline & Daily & 299 & 56.5 \\
\hline
\end{tabular}

Table 2

Prevalence of body dissatisfaction

\begin{tabular}{lccc}
\hline & Boys \% & Girls \% & Total \% \\
\hline Satisfaction & 44.4 & 39.2 & 42.0 \\
Dissatisfaction & 55.6 & 60,8 & 58.0 \\
- Wants to be larger & 15.8 & 10.6 & 13.4 \\
- Wants to be thinner & 39.8 & 50.2 & 44.6 \\
\hline
\end{tabular}

The prevalence of overweight and obese subjects was $18.5 \%$ and $4.3 \%$, respectively. Significant differences were found in obesity prevalence by gender $\left(\chi^{2}(1)=22.88, \mathrm{p}<.000\right)$; obesity was higher in boys than girls $(31 \%$ vs. $13.5 \%)$.

As illustrated in Figure 1, a significant association was found between obesity and body dissatisfaction $\left(\chi^{2}(4)=86.76, p=.000\right)$. Obese 
and overweight adolescents were more dissatisfied with their body image $(95.7 \%$ and $77.6 \%$, respectively) and wished be thinner. Of the normal-weight group, only $49.8 \%$ were satisfied with their body image.

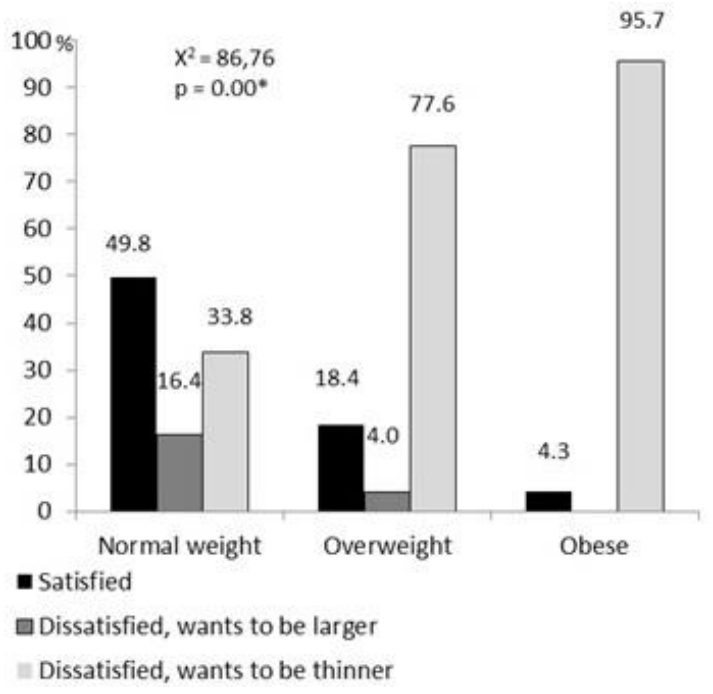

Figure 1. Prevalence of body image dissatisfaction by obesity

Univariate logistic regression revealed that the following variables are associated with body dissatisfaction (Table 3): obesity ( $\mathrm{OR}=5.32$; IC95\%: 3.14-9.00), watching TV more than two hours per day $(\mathrm{OR}=1.85$; IC95\%: 1.11-3.07; $\mathrm{OR}=2.04$; IC95\%: 1.28-3.26) and four or more days per week of sports activities $(\mathrm{OR}=0.53$; IC95\%: 0.35-0.81). In the final model, attained by multivariate logistic regression, the variables that maintained the association were the same: obesity (OR=6.94; IC95\%: 3.86-12.49), four or more days per week of sport activities ( $\mathrm{OR}=0.52$; IC95\%: 0.32-0.84) and watching TV more than two hours per day (OR=2.22; IC95\%: 1.25-3.94; $\mathrm{OR}=2.28$; IC95\%: 1.35-3.84).

Separate logistic regressions (univariate and multivariate) were conducted for female and male adolescents in order to identify the variables that were associated with body image dissatisfaction for each gender (see Table 4). Among male adolescents, the variables that showed a significant association by univariate logistic regression were obesity $(\mathrm{OR}=5.23$; IC95\%: 2.87-9.53), four or more days per week of sports activities (OR=0.55; IC95\%: 0.32-0.95) and watching TV more than two hours per day $(\mathrm{OR}=2.30$; IC95\%: 1.15-4.62; OR=3.22; IC95\%:
1.67-6.20). In the final model, the variables that kept the association were obesity $(\mathrm{OR}=6.46$; IC95\%: 3.26-12.81) and watching TV more than two hours per day (OR=2.50; IC95\%: 1.13-5.53; $\mathrm{OR}=3.34$; IC95\%: 1.57-7.11).

Among female adolescents, obesity was the only variable that had a significant association with body dissatisfaction, on both univariate $(\mathrm{OR}=12.35 ; \quad \mathrm{IC} 95 \%: \quad 2.88-52.92) \quad$ and multivariate ( $\mathrm{OR}=12.55$; IC95\%: 2.92-53.99) logistic regressions.

Table 3

Unadjusted and adjusted ${ }^{1}$ odds ratios and 95\% confidence intervals of body dissatisfaction by sociodemographic and lifestyle factors for total sample

\begin{tabular}{|c|c|c|}
\hline \multirow[b]{2}{*}{ Variable } & \multicolumn{2}{|c|}{ Total sample } \\
\hline & $\begin{array}{c}\text { Unadjusted } \\
\text { OR }(95 \% \text { CI) }\end{array}$ & $\begin{array}{c}\text { Adjusted } \\
\text { OR }(95 \% \mathrm{CI})\end{array}$ \\
\hline \multicolumn{3}{|l|}{ Gender } \\
\hline Male & 1.00 & \\
\hline Female & $1.24(0.88-1.72)$ & \\
\hline \multicolumn{3}{|l|}{ Age } \\
\hline$\leq 13.5$ years & 1.00 & \\
\hline$>13.5$ years & $0.96(0.68-1.36)$ & \\
\hline \multicolumn{3}{|l|}{ Obesity } \\
\hline Normal Weight & 1.00 & 1.00 \\
\hline Obese & $5.32(3.14-9.00)$ & $6.94(3.86-12.49)$ \\
\hline \multicolumn{3}{|c|}{ Mother Educational Level } \\
\hline$\leq 4$ years & 1.00 & \\
\hline $5-6$ years & $1.11(0.73-1.68)$ & \\
\hline$\geq 7$ years & $1.28(0.83-1.99)$ & \\
\hline \multicolumn{3}{|c|}{ Father Educational Level } \\
\hline$\leq 4$ years & 1.00 & 1.00 \\
\hline $5-6$ years & $1.35(0.89-2.04)$ & $1.43(0.92-2.25)$ \\
\hline$\geq 7$ years & $0.86(0.55-1.35)$ & $0.87(0.51-1.37)$ \\
\hline \multicolumn{3}{|l|}{ Sports Activity } \\
\hline 0-1 day/week & 1.00 & 1.00 \\
\hline 2-3 days/week & $1.34(0.86-2.08)$ & $1.34(0.83-2.17)$ \\
\hline$\geq 4$ days/week & $0.53(0.35-0.81)$ & $0.52(0.32-0.84)$ \\
\hline \multicolumn{3}{|l|}{ TV (weekday) } \\
\hline 1 hour/day & 1.00 & 1.00 \\
\hline 2 hours/day & $1.85(1.11-3.07)$ & $2.22(1.25-3.94)$ \\
\hline$\geq 3$ hours/day & $2.04(1.28-3.26)$ & $2.28(1.35-3.84)$ \\
\hline \multicolumn{3}{|l|}{ Smoking } \\
\hline No & 1.00 & \\
\hline Yes & $1.47(0.65-3.35)$ & \\
\hline \multicolumn{3}{|l|}{ Alcohol } \\
\hline No & 1.00 & \\
\hline Yes & $0.88(0.55-1.40)$ & \\
\hline \multicolumn{3}{|l|}{3 meals/day } \\
\hline No & 1.00 & \\
\hline Yes & $1.07(0.71-1.60)$ & \\
\hline \multicolumn{3}{|l|}{ Soft Drinks } \\
\hline Never & 1.00 & \\
\hline Weekly & $2.02(0.68-5.95)$ & \\
\hline Daily & $1.68(0.56-5.01)$ & \\
\hline \multicolumn{3}{|l|}{ Fruit } \\
\hline Never & 1.00 & 1.00 \\
\hline Weekly & $8.33(0.96-72.55)$ & $6.24(0.69-56.46)$ \\
\hline Daily & $6.24(0.72-54.07)$ & $4.31(0.48-38.76)$ \\
\hline
\end{tabular}


Table 4

Unadjusted and adjusted ${ }^{1}$ odds ratios (OR) and 95\% confidence intervals (95\% CI) of body dissatisfaction by socio-demographic and lifestyle factors by gender

\begin{tabular}{|c|c|c|c|c|}
\hline \multirow[b]{2}{*}{ Variable } & \multicolumn{2}{|c|}{ Male } & \multicolumn{2}{|c|}{ Female } \\
\hline & $\begin{array}{l}\text { Unadjusted } \\
\text { OR }(95 \% \text { CI })\end{array}$ & $\begin{array}{c}\text { Adjusted } \\
\text { OR }(95 \% \text { CI })\end{array}$ & $\begin{array}{c}\text { Unadjusted } \\
\text { OR }(95 \% \text { CI })\end{array}$ & $\begin{array}{c}\text { Adjusted } \\
\text { OR }(95 \% \mathrm{CI})\end{array}$ \\
\hline \multicolumn{5}{|l|}{ Age } \\
\hline$\leq 13.5$ years & 1.00 & & 1.00 & \\
\hline$>13.5$ years & $0.93(0.58-1.49)$ & & $0.98(0.58-1.63)$ & \\
\hline \multicolumn{5}{|l|}{ Obesity } \\
\hline Normal Weight & 1.00 & 1.00 & 1.00 & 1.00 \\
\hline Obese & $5.23(2.87-9.53)$ & $6.46(3.26-12.81)$ & $12.35(2.88-52.92)$ & $12.55(2.92-53.99)$ \\
\hline \multicolumn{5}{|c|}{ Mother Educational Level } \\
\hline$\leq 4$ years & 1.00 & 1.00 & 1.00 & \\
\hline $5-6$ years & $1.34(0.76-2.35)$ & $1.11(0.58-2.14)$ & $0.94(0.50-1.74)$ & \\
\hline$\geq 7$ years & $1.83(0.99-3.36)$ & $1.49(0.69-3.25)$ & $0.88(0.46-1.66)$ & \\
\hline \multicolumn{5}{|c|}{ Father Educational Level } \\
\hline$\leq 4$ years & 1.00 & 1.00 & 1.00 & \\
\hline $5-6$ years & $1.46(0.83-2.58)$ & $1.76(0.91-3.39)$ & $1.27(0.69-2.32)$ & \\
\hline$\geq 7$ years & $1.07(0.59-1.95)$ & $1.02(0.48-2.22)$ & $0.68(0.35-1.33)$ & \\
\hline \multicolumn{5}{|l|}{ Sports Activity } \\
\hline 0-1 day/week & 1.00 & 1.00 & 1.00 & 1.00 \\
\hline 2-3 days/week & $1.49(0.81-2.75)$ & $1.44(0.72-2.88)$ & $1.21(0.62-2.35)$ & $1.22(0.61-2.42)$ \\
\hline$\geq 4$ days/week & $0.55(0.32-0.95)$ & $0.55(0.29-1.04)$ & $0.59(0.27-1.27)$ & $0.56(0.25-1.27)$ \\
\hline \multicolumn{5}{|l|}{ TV (weekday) } \\
\hline 1 hour/day & 1.00 & 1.00 & 1.00 & \\
\hline 2 hours/day & $2.30(1.15-4.62)$ & $2.50(1.13-5.53)$ & $1.50(0.69-3.25)$ & \\
\hline$\geq 3$ hours/day & $3.22(1.67-6.20)$ & $3.34(1.57-7.11)$ & $1.22(0.62-2.42)$ & \\
\hline \multicolumn{5}{|l|}{ Smoking } \\
\hline No & 1.00 & & 1.00 & \\
\hline Yes & $1.15(0.42-3.11)$ & & $2.67(0.55-12.84)$ & \\
\hline \multicolumn{5}{|l|}{ Alcohol } \\
\hline No & 1.00 & & 1.00 & \\
\hline Yes & $0.90(0.52-1.57)$ & & $1.01(0.38-2.71)$ & \\
\hline \multicolumn{5}{|l|}{3 meals/day } \\
\hline No & 1.00 & & 1.00 & \\
\hline Yes & $0.92(0.50-1.67)$ & & $1.13(0.65-1.97)$ & \\
\hline \multicolumn{5}{|l|}{ Soft Drinks } \\
\hline Never & 1.00 & & 1.00 & \\
\hline Weekly & $2.89(0.51-16.25)$ & & $1.58(0.38-6.53)$ & \\
\hline Daily & $2.23(0.39-12.61)$ & & $1.57(0.36-6.80)$ & \\
\hline \multicolumn{5}{|l|}{ Fruit } \\
\hline Never & 1.00 & 1.00 & * & \\
\hline Weekly & $4.92(0.53-45.40)$ & $3.03(0.31-29.72)$ & & \\
\hline Daily & $5.31(0.58-48.60)$ & $2.97(0.31-28.71)$ & & \\
\hline
\end{tabular}

\section{DISCUSSION}

O The results confirm a high prevalence of body image dissatisfaction in young people (1018 years), especially in overweight and obese adolescents. The risk factors associated with body image dissatisfaction are obesity and time spent watching TV, while sports activity is a preventive one.

The discrepancies concerning body image dissatisfaction prevalence between countries are due to several cultural, ethnic and socioeconomic variables, as well as the different instruments applied and dissimilar age samples. In this study, we found that the prevalence of body image dissatisfaction was $58 \%$. Similar results were observed in Brazilian adolescents (19.5\%-64.2) (Duca et al., 2010; Fidelix et al., 2011; Petroski et al., 2009), while lower results were found in Middle Eastern countries, ranging from $11.4 \%$ in Pakistan to $21.2 \%$ in Jordan (Alikasifoglu et al., 2011; Mousa, Mashal, Al-Domi, \& Jibril, 2010; Mumford, Whitehouse, \& Choudry, 1992). This discrepancy can be explained by greater social and cultural similarities between Portugal and Brazil than between these countries and Middle Eastern nations. 
However, while in the past body image concerns may have been more often associated with women, today both genders share these concerns, but for different reasons. The results of this study are consistent with previous studies (Fountoulakis \& Grogan, 2014; Petroski et al., 2009; Silva et al., 2011; Triches \& Giugliani, 2007): girls want to lose weight to become thinner, while boys want to gain weight and increase muscle mass. Two possible explanations may justify this: greater media influence on women's beauty standards (Posavac \& Posavac, 2002) and men's pursuit of lean, muscular bodies (Cafri et al., 2005). A qualitative study done by Hargreaves and Tiggemann (2006) on boys' body image (14-16 years old) reinforces the finding that the subjects do not believe mass media influences their body image.

In accordance with other studies (Alikasifoglu et al., 2011; Almeida, 2004; Costa \& Vasconcelos, 2010; Duca et al., 2010; GilbertDiamond et al., 2009; Martins et al., 2010; Pallan, Hiam, Duda, \& Adab, 2011; Petroski et al., 2009; Santana et al., 2013; Silva et al., 2011; Triches \& Giugliani, 2007), our results revealed the prevalence of obesity as one of the most important factors in development of body dissatisfaction, with obese subjects presenting a risk for dissatisfaction seven times higher than their normal-weight peers. Obesity was the only variable associated with body dissatisfaction in females, and showed a higher risk than for males. Presnell, Bearman, and Stice (2004) have suggested that girls are dissatisfied with their bodies regardless of their weight, whereas boys become concerned only when they are overweight.

In effect, obese participants revealed higher body image dissatisfaction than normal-weight participants. Still, half of normal-weight participants desired to be thinner. Today, Western societies demand thinner body profiles, and through enculturation processes, younger people absorb these references at an early age. Similar to our investigation, the study developed by Al Sabbah et al. (2009) of adolescents (11-15 years) in 24 European countries, the USA and Canada also found high body image dissatisfaction in obese (between $54.0 \%$ and
$85.4 \%$ ) and in non-overweight (between $22,5 \%$ and $45.1 \%$ ) adolescents.

While demographic variables such as gender and age have been reported in the literature as associated with body dissatisfaction (Alikasifoglu et al., 2011; Almeida, 2004; Duca et al., 2010; Fidelix et al., 2011; Silva et al., 2011), results from the present study did not confirm this association. Parental schooling was also not associated with body dissatisfaction, meaning that children from different social classes seem to be exposed to the same messages of body image from family, friends and the media (Pinheiro \& Giugliani, 2006).

On the other hand, sports activity was the only variable acting as a preventive factor for body image dissatisfaction. A cross-sectional study with Portuguese adolescents (10-17 years) reached the same conclusion - higher levels of physical activity were associated with a protective effect on body dissatisfaction (Gaspar et al., 2011). The results of a longitudinal research showed that participation in 6 weeks aerobic dance reduced body dissatisfaction among adolescent girls (Burgess et al., 2006). Two recent meta-analysis studies also proved that physical exercise is associated with a more positive body image (Campbell \& Hausenblas, 2009; Hausenblas \& Fallon, 2006). The higher proprioceptive information input and somatosensory conscience given by exercise (Damásio, 2000) allows for a better body image. On the other hand, Costa and Vasconcelos (2010) did not find this association, though their results might be explained by the method used to assess physical activity (a dichotomic scale: practice/no practice), which disallows differentiation in amount of practice per week. We highlight the positive association of physical activity four or more days per week.

The hours spent daily watching television during the week also showed a significant association with body image dissatisfaction in males and in the total sample. Similar results were found by Alikasifoglu et al. (2011). Adolescents who spend more than two hours/day watching TV have double the risk of body image dissatisfaction compared to those who watch up to one hour per day. The risk is 
three times higher in males who watch more than three hours/day. This could be due to the fact that time spent watching TV is one of the sedentary activities most commonly associated with obesity (Marshall, Biddle, Gorely, Cameron, \& Murdey, 2004), as well as to TV's role in promoting beauty ideals such as thinness and hyper-caloric food intake.

Lifestyle factors, dietary patterns and substances consumption (alcohol and smoking) were not associated with body image dissatisfaction in our study. However, Duca et al. (2010) showed that adolescents who want to lose weight more frequently adhere to induced vomiting, medication intake and smoking habits, and eat fewer than three meals daily. Silva, Nahas, de Sousa, Del Duca, and Peres (2011) found an association between alcohol abuse and body image dissatisfaction in males (with drinkers having a 1.7 times higher risk for dissatisfaction).

Several limitations should be highlighted in this study and need to be kept in mind when analyzing the results. First, the cross-sectional design cannot establish cause-effect relationships. Second, the use of a convenience sample restricts generalization and inference about populations. Third, the study did not include psychological variables, such as negative mood, depression, self-esteem and perfectionism, variables that have also been cited as associated with body image dissatisfaction.

Some of this study's strengths lie in the analysis of factors associated with body image dissatisfaction by gender (a gap in the literature) and in the use of a multivariate logistic regression with the inclusion of several background variables, allowing determination of risk and preventive factors associated with body dissatisfaction in order to design differentiated public heath interventions to reduced body dissatisfaction.

\section{CONCLUSIONS}

The current findings confirm a high prevalence of body image dissatisfaction in young people (58\%), especially in overweight and obese adolescents. Obesity is a risk factor of body image dissatisfaction for both, male and female; while for boys, the time spent watching TV is a risk factor and sports activity is a preventive one .It is necessary to consider a different intervention for men and women in order to reduce body image dissatisfaction. Recent public health guidelines highlight the importance of minimizing time spent sitting in adolescents, mainly the time young male spent watching television. The adoption of an active lifestyle and healthy eating habits can contribute significantly to the promotion of a more positive body image.

\section{Acknowledgments:}

Nothing to declare

\section{Conflict of Interest:}

Nothing to declare

\section{Funding:}

Nothing to declare

\section{REFERENCES}

Al Sabbah, H., Vereecken, C. A., Elgar, F. J., Nansel, T., Aasvee, K., Abdeen, Z., ... Maes, L. (2009). Body weight dissatisfaction and communication with parents among adolescents in 24 countries: international cross-sectional survey. BMC Public Health, 9, 52. http://doi.org/10.1186/14712458-9-52

Alikasifoglu, M., Ercan, O., Erginoz, E., AlbayearakKaymak, D., \& Uysal, O. (2011). Factors Associated with Dissatisfaction of Body Image among Turkish Adolescents. Journal of Adolescent Health, 48(2), S53. http://doi.org/10.1016/j.jadohealth.2010.11.11 4

Almeida, A. M. D. (2004). Insatisfação com o peso corporal. Revista Portuguesa de Medicina Geral e Familiar, 20(6), 651-66.

Burgess, G., Grogan, S., \& Burwitz, L. (2006). Effects of a 6-week aerobic dance intervention on body image and physical self-perceptions in adolescent girls. Body Image, 3(1), 57-66. http://doi.org/10.1016/j.bodyim.2005.10.005

Cafri, G., Thompson, J. K., Ricciardelli, L., McCabe, M., Smolak, L., \& Yesalis, C. (2005). Pursuit of the muscular ideal: Physical and psychological consequences and putative risk factors. Clinical Psychology Review, 25(2), 215-239. http://doi.org/10.1016/j.cpr.2004.09.003

Campbell, A., \& Hausenblas, H. A. (2009). Effects of exercise interventions on body image: a metaanalysis. Journal of Health Psychology, 14(6), 
780-793.

http://doi.org/10.1177/1359105309338977

Coelho, E. M., Padez, C., Moreira, P., Rosado, V., \& Mourão-Carvalhal, I. (2013). BMI and selfperceived body shape in Portuguese children. Revista de Psicología del Deporte, 22(2), 371376.

Cole, T. J., Bellizzi, M. C., Flegal, K. M., \& Dietz, W. H. (2000). Establishing a standard definition for child overweight and obesity worldwide: international survey. BMJ, 320(7244), 12401243.

http://doi.org/10.1136/bmj.320.7244.1240

Collins, M. E. (1991). Body figure perceptions and preferences among preadolescent children. International Journal of Eating Disorders, 10(2), 199-208. http://doi.org/10.1002/1098108X(199103) 10:2<199::AIDEAT2260100209>3.0.CO;2-D

Costa, L. da C. F., \& Vasconcelos, F. de A. G. de. (2010). Influência de fatores socioeconômicos, comportamentais e nutricionais na insatisfação com a imagem corporal de universitárias em Florianópolis, SC. Revista Brasileira de Epidemiologia, 13(4), 665-676. http://doi.org/10.1590/S1415$790 \times 2010000400011$

Damásio, A. (2000). O sentimento de si: o corpo, a emoção e a neurobiologia da consciência. MemMartins: Publicações Europa-América.

Dohnt, H. K., \& Tiggemann, M. (2006). Body Image Concerns in Young Girls: The Role of Peers and Media Prior to Adolescence. Journal of Youth and Adolescence, 35(2), 135. http://doi.org/10.1007/s10964-005-9020-7

Duca, D., Firpo, G., Garcia, L. M. T., Sousa, T. F. de, Oliveira, E. S. A. de, \& Nahas, M. V. (2010). Insatisfação com o peso corporal e fatores associados em adolescentes. Revista Paulista de Pediatria, 28(4), 340-346. http://doi.org/10.1590/S010305822010000400009

Fidelix, Y. L., Silva, D. A. S., Pelegrini, A., Silva, A. F. da, \& Petroski, E. L. (2011). Body image dissatisfaction among adolescents from a small town: association with gender, age, and area of residence. Revista Brasileira de Cineantropometria \& Desempenho Humano, 13(3), 202-207. http://doi.org/10.5007/19800037.2011v13n3p202

Fountoulakis, C., \& Grogan, S. (2014). An investigation of the links between body image and exercise participation. Sport \& Exercise Psychology Review, 198(11), 19-30.

Gaspar, M. J. M., Amaral, T. F., Oliveira, B. M. P. M., \& Borges, N. (2011). Protective effect of physical activity on dissatisfaction with body image in children - A cross-sectional study. Psychology of Sport and Exercise, 12(5), 563-569. http://doi.org/10.1016/j.psychsport.2011.05.00 4
Gilbert-Diamond, D., Baylin, A., Mora-Plazas, M., \& Villamor, E. (2009). Correlates of obesity and body image in Colombian women. Journal of Women's Health (2002), 18(8), 1145-1151. http://doi.org/10.1089/jwh.2008.1179

Hargreaves, D. A., \& Tiggemann, M. (2006). «Body image is for girls»: a qualitative study of boys' body image. Journal of Health Psychology, 11(4), 567-576. http://doi.org/10.1177/1359105306065017

Harriss, D. J., \& Atkinson, G. (2009). International Journal of Sports Medicine - ethical standards in sport and exercise science research. International Journal of Sports Medicine, 30(10), 701-702. http://doi.org/10.1055/s-0029-1237378

Hausenblas, H. A., \& Fallon, E. A. (2006). Exercise and body image: A meta-analysis. Psychology \& Health, 21(1), 33-47. http://doi.org/10.1080/14768320500105270

Kantanista, A., Osiński, W., Borowiec, J., Tomczak, M., \& Król-Zielińska, M. (2015). Body image, BMI, and physical activity in girls and boys aged 14-16 years. Body Image, 15, 40-43. http://doi.org/10.1016/j.bodyim.2015.05.001

Kim, D.-S., \& Kim, H.-S. (2009). Body-image dissatisfaction as a predictor of suicidal ideation among Korean boys and girls in different stages of adolescence: a two-year longitudinal study. The Journal of Adolescent Health: Official Publication of the Society for Adolescent Medicine, 45(1), 47-54. http://doi.org/10.1016/j.jadohealth.2008.11.01 7

Kirkcaldy, B. D., Shephard, R. J., \& Siefen, R. G. (2002). The relationship between physical activity and self-image and problem behaviour among adolescents. Social Psychiatry and Psychiatric Epidemiology, 37(11), 544-550. http://doi.org/10.1007/s00127-002-0554-7

Kruger, J., Lee, C.-D., Ainsworth, B. E., \& Macera, C. A. (2008). Body size satisfaction and physical activity levels among men and women. Obesity (Silver Spring, Md.), 16(8), 1976-1979. http://doi.org/10.1038/oby.2008.311

Littleton, H. L., \& Ollendick, T. (2003). Negative body image and disordered eating behavior in children and adolescents: what places youth at risk and how can these problems be prevented? Clinical Child and Family Psychology Review, 6(1), 5166.

Marshall, S. J., Biddle, S. J. H., Gorely, T., Cameron, N., \& Murdey, I. (2004). Relationships between media use, body fatness and physical activity in children and youth: a meta-analysis. International Journal of Obesity and Related Metabolic Disorders: Journal of the International Association for the Study of Obesity, 28(10), 1238-1246. http://doi.org/10.1038/sj.ijo.0802706

Martins, C. R., Pelegrini, A., Matheus, S. C., \& Petroski, E. L. (2010). Body image dissatisfaction and its relationship with nutritional status, body 
fat, and anorexia and bulimia symptoms in adolescents. Revista de Psiquiatria do Rio Grande do Sul, 32(1), 19-23. http://doi.org/10.1590/S010181082010000100004

Mousa, T. Y., Mashal, R. H., Al-Domi, H. A., \& Jibril, M. A. (2010). Body image dissatisfaction among adolescent schoolgirls in Jordan. Body Image, $7(1)$, $46-50$. http://doi.org/10.1016/j.bodyim.2009.10.002

Mumford, D. B., Whitehouse, A. M., \& Choudry, I. Y. (1992). Survey of eating disorders in Englishmedium schools in Lahore, Pakistan. The International Journal of Eating Disorders, 11(2), 173-184.

Pallan, M. J., Hiam, L. C., Duda, J. L., \& Adab, P. (2011). Body image, body dissatisfaction and weight status in south asian children: a crosssectional study. BMC Public Health, 11, 21. http://doi.org/10.1186/1471-2458-11-21

Petroski, E. L., Pelegrini, A., \& Glaner, M. F. (2009). Body image dissatisfaction among rural and urban adolescents. Motricidade, 5(4), 13-25. http://doi.org/10.6063/motricidade.5(4).167

Pinheiro, A. P., \& Giugliani, E. R. J. (2006). Body dissatisfaction in Brazilian schoolchildren: prevalence and associated factors. Revista de Saúde Pública, 40(3), 489-496. http://doi.org/10.1590/S003489102006000300018

Posavac, S. S., \& Posavac, H. D. (2002). Predictors of women's concern with body weight: the roles of perceived self-media ideal discrepancies and selfesteem. Eating Disorders, 10(2), 153-160. http://doi.org/10.1002/erv.462

Presnell, K., Bearman, S. K., \& Stice, E. (2004). Risk factors for body dissatisfaction in adolescent boys and girls: a prospective study. The International Journal of Eating Disorders, 36(4), 389-401. http://doi.org/10.1002/eat.20045

Santana, M. L. P., Silva, R. de C. R., Assis, A. M. O., Raich, R. M., Machado, M. E. P. C., de J Pinto, E., ... Ribeiro Júnior, H. da C. (2013). Factors associated with body image dissatisfaction among adolescents in public schools students in Salvador, Brazil. Nutrición Hospitalaria, 28(3), 747-755.

http://doi.org/10.3305/nh.2013.28.3.6281

Shin, N. Y., \& Shin, M. S. (2008). Body dissatisfaction, self-esteem, and depression in obese Korean children. The Journal of Pediatrics, 152(4), 502506. http://doi.org/10.1016/j.jpeds.2007.09.020

Silva, D. A. S., Nahas, M. V., de Sousa, T. F., Del Duca, G. F., \& Peres, K. G. (2011). Prevalence and associated factors with body image dissatisfaction among adults in southern Brazil: A population-based study. Body Image, 8(4), 427-431. http://doi.org/10.1016/j.bodyim.2011.05.009

Slade, P. D. (1994). What is body image? Behaviour Research and Therapy, 32(5), 497-502.

Stice, E., \& Bearman, S. K. (2001). Body-image and eating disturbances prospectively predict increases in depressive symptoms in adolescent girls: a growth curve analysis. Developmental Psychology, 37(5), 597-607. http://doi.org/10.1037//0012-1649.37.5.597

Stice, E., Hayward, C., Cameron, R. P., Killen, J. D., \& Taylor, C. B. (2000). Body-image and eating disturbances predict onset of depression among female adolescents: a longitudinal study. Journal of Abnormal Psychology, 109(3), 438-444.

Triches, R. M., \& Giugliani, E. R. J. (2007). Body dissatisfaction in school children from two cities in the South of Brazil. Revista de Nutrição, 20(2), 119-128. http://doi.org/10.1590/S141552732007000200001

van den Berg, P. A., Mond, J., Eisenberg, M., Ackard, D., \& Neumark-Sztainer, D. (2010). The link between body dissatisfaction and self-esteem in adolescents: similarities across gender, age, weight status, race/ethnicity, and socioeconomic status. The Journal of Adolescent Health: Official Publication of the Society for Adolescent Medicine, 47(3), 290-296. http://doi.org/10.1016/j.jadohealth.2010.02.00 4 